\title{
Restoring Democracy to the Workplace? An Analysis of Union Membership Patterns Before and After the Employment Contracts Act
}

\author{
Christina Cregan, Chris Rudd and Stewart Johnston*
}

This paper investigates the impact of the Employment Contracts Act on trade union membership. Two separate surveys of labour market participants were conducted in Dunedin on the eve of the legislation and one year later. The findings demonstrated that for these samples, trade union membership in aggregate was not based on compulsion before the legislation, and remained at a similar level a year later. Democracy was not restored to the workplace: it was already apparent there. This implies that changes in the industrial relations system had already taken place prior to the legislation and it is suggested that these findings are explicable if the effect of the exigencies of the recession on both parties is taken account of. In the ensuing discussion, reasons for the persistence of the same level of union membership after the legislation were considered. It was demonstrated that most members wanted the union to act as their bargaining agent and felt few pressures regarding their choice of employment contract. In other words, employers did not utilise the provisions of the Act to weaken union membership, at least in the short term.

\section{Introduction}

The Employment Contracts Act was heralded by the Government as a radical piece of legislation, essential if the New Zealand economy were to be revitalised. According to Bill Birch, Minister of Labour, then acting spokesperson on industrial relations, "to provide dramatically improved productivity, income and employment, we must bring a far more flexible structure into industrial relations .... (W)e intend . . . to bring true democracy to the workplace." (National Party Manifesto, 1991: 26). The argument put forward was that the support given by the state to trade unions allowed them sufficient strength to adversely

Christina Cregan, Department of Economics, Chris Rudd, Department of Political Science and Stewart Johnston, Department of Management, University of Otago. The authors wish to thank Valerie Thompson, Sue Cathro and Glennis Salmon for their assistance. 
affect the economy, by increasing costs, reducing potential productivity and resisting technological change ${ }^{1}$. The implication was that if employees were allowed free choice about their union membership decision and could negotiate their form of employment contract, unions would be less powerful.

Several important empirical investigations have been carried out in New Zealand concerning the likely or early effects of the legislation on bargaining procedures (Harbridge, 1991; McAndrew, 1992; Harbridge and Moulder, 1992), and on wages and productivity (Harbridge and Moulder, 1992) which suggest that some significant changes have occurred since the enactment of the legislation. It is not at all clear, however, that these have come about wholly as direct consequences of the Act. In particular, it might be dangerous to assume that any perceived benefits to the national interest result from the weakening of union power, particularly through a process of workplace democracisation.

The aim of this paper, therefore, is to examine, not the effects of the Act, but the mechanism which is said to bring about such changes: union membership and freedom of individual choice. The character of trade union membership will be examined to determine the extent of its compulsory element before and after the legislation by questioning those directly affected by the Act: labour market participants. The paper will be organised in the following way. Following the presentation and discussion of the data, a hypothesis will be set up underpinning the issue. This will be tested by appropriate analysis of the data. There will be a discussion of the results and a consideration of their implications.

\section{Data}

In May 1991, during the week of the passage of the Employment Contracts Act, a postal questionnaire survey was carried out in Dunedin of a random sample of employed adults. The same sample, part of which was no longer employed, was recontacted in the same way one year later (May 1992) and consequently, we were able to directly examine any changes experienced by the same group of people. For purposes of comparison and validation, a further random sample of employed and unemployed adults was also surveyed in May 1992. All investigations were carried out in Dunedin. The first survey took place on the eve of the passage of the new legislation. Five hundred names of employed adults were drawn, using random sampling, from the 1988 electoral rolls, based on the 1986 Census, for the three Dunedin electorates of Dunedin North, St Kilda and Dunedin West. Questionnaires accompanied by prepaid reply envelopes were sent out during the first week of May 1991. One hundred and eighty five responses were received and, after three weeks, reminders were sent to those who had not yet replied. A total of 234 replies were received, a response rate of 47 percent. Of these, 95 (41 percent) were female, 157 (67 percent) were married and 105 (45 percent) supported between one and three children. The age range was between 19 and 69 with a mean of 39 and there was no significant difference between the ages of the genders.

Since the 1950 s, in international terms, the economy had declined. New Zealand's relative standard of living, as measured by per capita GDP, had fallen from the third highest in the world in 1950 to the eighth in 1955 to the twenty-third in 1987 (Crocombe, Enright and Porter, 1991). 
There were two separate samples investigated in the May 1992 survey. The first consisted of recontacts from the investigation of May 1991 so that we could directly examine a change in attitudes of the same cohort without relying on hindsight. A second random sample was taken from the 1991 electoral rolls because we wanted to compare findings from the recontacts with those of a random sample of labour force participants in order to identify any bias that might be apparent in a sample of recontacts. As some of the latter were no longer in work in May 1992, we included the unemployed in the new random sample. Questionnaires, with prepaid envelopes, were posted on 25 May 1992 to 514 people. Two hundred and twenty were employed in May 1991, had replied to the earlier survey and were still apparent in the 1991 electoral rolls drawn from the 1991 Census. The remaining 294 were employed and unemployed adults randomly chosen. By 11 June, 85 ( 38 percent) of the recontacts, and 88 ( 30 percent) of the new sample had responded. A reminder was sent out three weeks later on $15 \mathrm{June}$, and by $31 \mathrm{July}^{2}, 136$ ( 62 percent) of the recontacts and 130 ( 44 percent) of the new sample had responded ${ }^{3}$.

The response rate from the May 1992 sample (44 percent) was very similar to that of the previous year ( 47 percent). We were unsurprised that the recontact rate (62 percent) was higher because these individuals were known respondents. Of the recontacts, 52 (38 percent) were female; of the random sample, 54 ( 42 percent) were female. Thus, there was no major difference in gender proportions between the three samples.

Although these response rates were high for random general populace postal questionnaires, the representativeness of the samples for Dunedin and for New Zealand must still be considered. For example, Dunedin does not represent either the farming or the Polynesian communities. Moreover, in each sample, because media conjecture about the Act tended to be in abstract or ideological form, those politically or economically unaware or disinterested may have been less motivated to respond and the self-administered nature of the questionnaire meant that a certain level of literacy was necessary. These reasons may account for the particular character of these samples (see Table 1): over-representation of the professional/managerial group (see Appendix 1) relative to Dunedin as a city and New Zealand in general.

In the first study (May 1991), the managerial/professional group accounted for nearly half (47 percent) of this sample, and white collar workers as a whole group, for two-thirds (67 percent). These figures are much higher than the corresponding ones for Dunedin (26 percent and 54 percent respectively) and New Zealand (21 percent and 47 percent). Although most of both genders worked full-time, unsurprisingly many more males than females had full-time employment $(\mathrm{p}<0.001)$ and only five males (four percent) worked part-time. In terms of occupation type, more women than men were engaged in sales/

2 The last response to the first survey arrived slightly earlier, on 18 July . However, this is not important for purposes of comparison because, by 9 July 1992, we had received 131 replies from each sample.

3 Twenty-nine surveys were returned for a number of reasons: wrong address, respondent retired or out of country, refused to answer. Five more were posted to us several weeks later and were excluded because they were subject to longer term influences. 
Table 1: Occupations and job characteristics

\begin{tabular}{|c|c|c|c|c|c|c|c|c|c|}
\hline & \multicolumn{3}{|c|}{ May 1991} & \multicolumn{6}{|c|}{ May 1992} \\
\hline & \multirow[b]{2}{*}{$F^{*}(\%)$} & \multirow[b]{2}{*}{$\mathrm{M}(\%)$} & \multirow[b]{2}{*}{$\operatorname{ALL}(\%)$} & \multicolumn{3}{|c|}{ Recontacts } & \multicolumn{3}{|c|}{ Random Sample } \\
\hline & & & & $F^{*}(\%)$ & $\mathrm{M}(\%)$ & ALL(\%) & $F^{*}(\%)$ & $\mathrm{M}(\%)$ & ALL(\%) \\
\hline Professional & $40(45)$ & $66(49)$ & $106(47)$ & 04(08) & $20(24)$ & $24(18)$ & $2(04)$ & $8(1)$ & $10(08)$ \\
\hline /managerial & & & & $11(22)$ & $21(25)$ & $32(24)$ & $23(44)$ & $19(24)$ & $42(32)$ \\
\hline Clerical/sec/sales/reception & $29(33)$ & $15(11)$ & $44(20)$ & $18(35)$ & $12(14)$ & $30(22)$ & $17(33)$ & $9(12)$ & $26(20)$ \\
\hline Service/manual & $18(20)$ & $49(36)$ & $67(30)$ & $18(35)$ & $32(38)$ & $50(37)$ & 10(19) & $42(54)$ & $52(40)$ \\
\hline \multirow[t]{2}{*}{ Farmer/farm labourer } & $2(02)$ & $5(04)$ & $7(3)$ & & 1 & & & & \\
\hline & 89 & 135 & 224 & 51 & 85 & 136 & 52 & 78 & 130 \\
\hline Full-time & $54(58)$ & $132(96)$ & $186(81)$ & $26(63)$ & $61(97)$ & $87(84)$ & $25(57)$ & $54(96)$ & $79(79)$ \\
\hline \multirow[t]{2}{*}{ Part-time } & $39(42)$ & $5(4)$ & $44(19)$ & $15(37)$ & $02(03)$ & $17(16)$ & $19(43)$ & $02(04)$ & $21(21)$ \\
\hline & 93 & 137 & 230 & 41 & 63 & 104 & 44 & 56 & 100 \\
\hline $\begin{array}{l}\text { In paid } \\
\text { employment }\end{array}$ & & & & $42(81)$ & $70(85)$ & $112(84)$ & $44(81)$ & $63(82)$ & $107(82)$ \\
\hline \multirow[t]{2}{*}{$\begin{array}{l}\text { Not in paid } \\
\text { employment }\end{array}$} & & & & $10(19)$ & $12(15)$ & $22(16)$ & $10(19)$ & $14(18)$ & $24(18)$ \\
\hline & & & & 52 & 82 & 134 & 54 & 77 & 131 \\
\hline
\end{tabular}

- Throughout, rounding may cause percentage total errors. 
clerical work, and more men then women in manual work ${ }^{4}$. These findings gave us some confidence that we could make useful comparisons between the genders, knowing that this sample reflected respective occupational distribution patterns.

In the second study (May 1992), in terms of occupation type taking account of missing data, for females the new random sample was similar in all respects to the random sample of May 1991. However, there were significantly fewer managerial/ profess-ional and significantly more manual workers in the male categories of the new sample. There was a drop-out rate of 39 percent for the recontacts ${ }^{5}$. Occupational differences between the samples will be taken account of in a discussion of the results.

In conclusion, in general the largest group in the samples consisted of white collar workers. Thus, these are biased samples. It may be that they over-represent those most interested, those most informed, or those most able to respond in writing. The bias will be taken account of when we interpret the results. However, attitudes of manual workers to an attack on trade union power seems easy to predict especially at a time of high unemployment, so it might be particularly interesting to have the opportunity to also investigate the views of white-collar workers, including managers and professionals, to the same situation.

\section{Hypothesis and investigations}

Our general proposition is that both employers and employees were already adjusting their industrial relations practices to the conditions of a long term recession before the new legislation. This meant that the impact of the Act did not have a "shock effect". Rather, it was an important stage in a long term political and economic process of deregulation apparent under both Labour and National Governments since 1984. With regard to union membership, the legislation current at the time of the survey was the 1987 Labour Relations Act which did not compulsorily impose union membership but allowed for it: if employer and union agreed to compulsory unionism or "unqualified preference" then such a clause could be inserted into an award or agreement. If there was no agreement, the workers could have a secret ballot, making membership compulsory by a majority vote. Adult workers so covered in either of these cases had to join within 14 days of being requested to do so by the union. However, employers were permitted, but not required to dismiss them if they declined. Consequently, there was adequate legal facility to allow for the existence of democratic choice regarding union membership prior to the Employment Contracts Act. It is hypothesised that it would have been taken advantage of by some employers desperate to cut costs and increase productivity and at a time when union membership was increasingly seen as producing fewer advantages for employees. The hypothesis suggests, therefore, that union membership status in general reflected the wishes

$4 \quad$ Managerial/professional was categorised separately for the recontacts, and it could be established that most of the women in that category were professionals and not managers.

5 This group demonstrated a difference from May 1991 with regard to women with proportionately significantly fewer managerial/professionals and more manual responding, but closer inspection of the data demonstrated that this was largely due to job changing and unemployment. Moreover, absolute numbers were too small to make any generalisations. 
of employees prior to the legislation which therefore would have little effect on membership patterns in the short term. It was possible to make several investigations of the data to test the proposition.

\section{Actual union membership}

In each of the surveys, each respondent was asked if he or she was currently a member of a trade union (see Table 2).

In May 1991, 50 percent claimed to be members and 47 percent non-members. For the recontacts in May 1992, the results were similar. Moreover, by directly comparing the response of each individual who answered both questionnaires, we were able to ascertain that very few individuals had changed their status. In the 1992 random sample, significantly more males were union members than in the similar random sample of May 1991 but this may have been due to the higher response rate of manual workers in the 1992 sample. Thus for these samples, only half were union members prior to the legislation and density had not fallen a year after its enactment.

\section{Desired union membership}

However, this result may merely demonstrate that the Act had been ineffective. We must therefore show that membership decisions in May 1991 reflected wishes. We were able to directly examine employee wishes, as opposed to actions, with regard to union membership (see Appendix 2). In May 1991, before the new legislation, most (70 percent) said that there was a union available for them to join at their place of work and the majority of these joined it: half of the sample were union members. Most of these members said that pressure had been put on them to join or that membership was a job requirement, but over three-quarters of these said they would have joined anyway. Moreover, those who would rather not have been members were matched in number by those who were non-members yet wished to join: there was no significant difference in overall responses between the proportions of members and non-members who would change their union status given free choice and absolute figures in this sample were the same (22 in each case). Furthermore, almost all had also been subject to pressures not to be union members. Finally, some of those who currently did not want to be in a union were prepared to admit that their view might change in a different situation: although the number of respondents to this question was small, just under a half of respondents (41 percent) implied that they would or might join in other circumstances. (Membership patterns of this sample are summarised in Appendix 3.)

However, it may be that some of them were "willing" members because they had been subject to ideological conversion by the presence of a union at the workplace. To explore this issue, all those who were in a union by "free choice" were asked, in an open-ended question, to provide reasons. Non-members who would have joined given the opportunity were also invited to respond (see Table 3 ). 
Union Membership Patterns

63

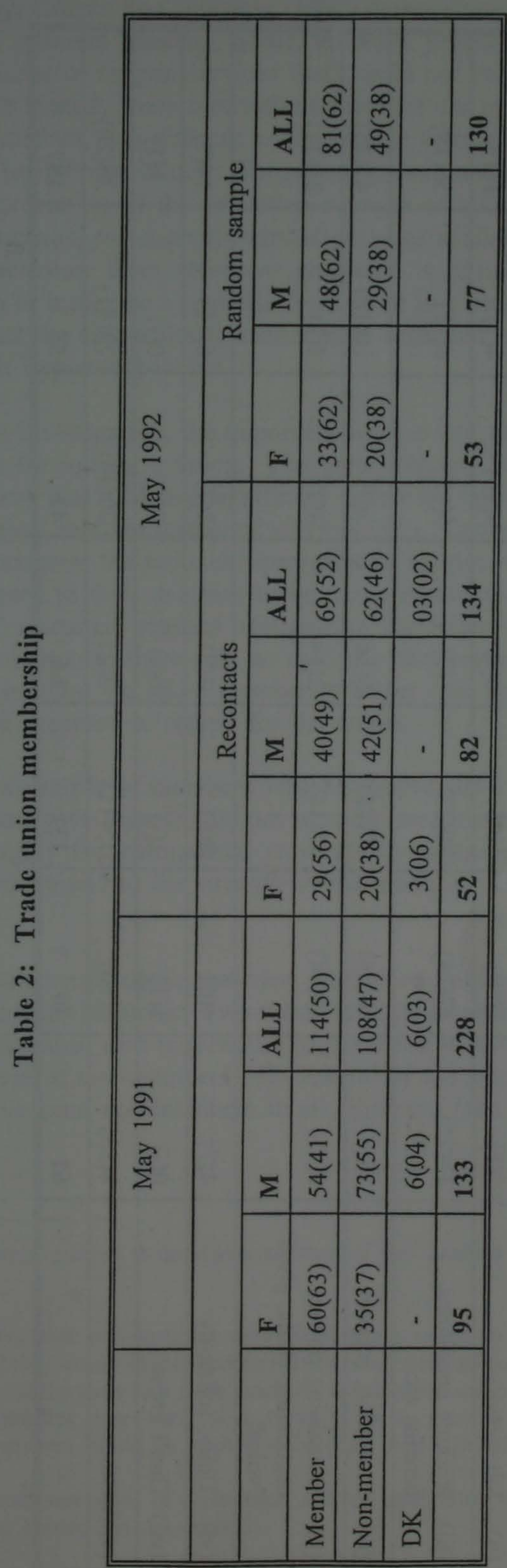


Table 3: Reasons for joining/wanting to join a trade union (May 1991)

\begin{tabular}{|c|c|c|c|c|c|c|c|c|}
\hline & & \multicolumn{3}{|c|}{ Members } & \multicolumn{3}{|c|}{ Non-Members } & \multirow[b]{2}{*}{ TOTAL(\%) } \\
\hline & & $F(\%)$ & $\mathrm{M}(\%)$ & ALL & $F(\%)$ & $\mathrm{M}(\%)$ & ALL(\%) & \\
\hline (i) & Wages & $4(7)$ & $6(9)$ & $10(8)$ & $0(-)$ & $2(5)$ & 2(4) & $12(6)$ \\
\hline (ii) & Job security & $5(8)$ & $7(10)$ & $12(9)$ & $0(-)$ & $4(10)$ & $4(7)$ & $16(9)$ \\
\hline (iii) & $\begin{array}{l}\text { Working conditions, } \\
\text { benefits etc }\end{array}$ & $13(21)$ & $17(24)$ & $30(23)$ & $1(7)$ & $5(12)$ & $6(11)$ & $36(19)$ \\
\hline (iv) & Protection, support & $19(31)$ & $18(26)$ & $37(28)$ & $5(36)$ & $5(7)$ & $10(18)$ & $47(25)$ \\
\hline (v) & $\begin{array}{l}\text { Bargaining power, } \\
\text { negotiating skills, gives } \\
\text { "voice" }\end{array}$ & $8(13)$ & $10(14)$ & $18(16)$ & $2(14)$ & $3(7)$ & $5(9)$ & $23(12)$ \\
\hline (vi) & Unity, solidarity & $4(7)$ & $4(6)$ & $8(6)$ & $3(21)$ & $3(7)$ & $6(11)$ & $14(7)$ \\
\hline (vii) & Don't know & $0(-)$ & $1(1)$ & $1(-)$ & $0(-)$ & $0(-)$ & $0(-)$ & $1(1)$ \\
\hline \multirow{2}{*}{\multicolumn{2}{|c|}{ (viii) Other }} & $8(13)$ & $7(10)$ & $15(11)$ & $3(21)$ & $20(48)$ & $23(41)$ & $38(20)$ \\
\hline & & 61 & 70 & 131 & 14 & 42 & 56 & 187 \\
\hline
\end{tabular}


In a British study, Cregan and Johnston (1990) demonstrated that employees joined unions for a number of different reasons. Some, the core, joined because of values or collective instrumental reasons or to gain services that could not be received by non-members, and it was possible to identify these motivations amongst our responses. Although motivations are analytically distinct, it is difficult to disentangle them empirically. However, unity and solidarity seem to indicate values. Bargaining power and voice (Hirschman, 1971) point clearly to an appreciation of the collective strength of union power. Working conditions, protection and support, job security were all services available to members only: in a time of increasing recession their defensive character is unsurprising. Wages might be a collective reason or it may be a response from those in a situation of unqualified preference. Fees demonstrates the conventional instrumental approach in which the costs of joining are seen to outweigh expected benefits.

In relation to our investigation, the important point is that values had very little importance in reasons given for joining a union. The great majority of reasons were instrumental in character and there was a highly significant difference between instrumental (categories i to $\mathrm{v})$ and ideological motives (category vi) $(\mathrm{p}<0.001)$. Consequently, despite the perception of workplace pressures, the rational, open-minded instrumentality of most workers in this survey with regard to their decision to be union members is a very clear finding. They were members for positive reasons, recognising the collective strength of unions for their protection ${ }^{6}$. Furthermore, there was no evidence that recruitment itself was prompted by ideological zeal because we asked members whether (see Appendix 2) and why (see Table 4) they would be prepared to recruit for the union.

In fact, nearly two-thirds of members who responded did not want to recruit at all, while those who did, and gave reasons, did not seem to have ideological purposes. They wanted others to join largely for instrumental reasons: to get the advantages they perceived that they had obtained, to add to the strength of the union, or through outrage at the free rider "theft"?

Finally, there was other evidence that mere workplace initiated pressure was not responsible for many membership decisions. Two-thirds of these Dunedin union members who replied, both males and females, said they would join a union in any situation. These results were in contrast to those of non-members ( 47 percent $^{8}$ of the sample), where just over a half of whom would have been non-members in all situations (see Appendix 2).

6 These findings replicate those of a recent study of New Zealand young people (Cregan and Johnston, 1992).

$? \quad$ Interestingly, when non-members were asked if they would try to persuade members to leave, only a tenth said they would do this, and no reasons at all were offered when asked directly. The fact that the success of the aims of a trade union lie in collective and not individual action and perhaps the outrage at the free rider "theft" seem to act as strong spurs to recruitment because more members than non-members would try to change the other party's decision.

8 When account was taken of compulsion and non-availability, 40 percent said they would be nonmembers by choice (see Appendix 3). 
Table 4: Members: reasons given for wanting to persuade non-members to join May (1991)

\begin{tabular}{||l|c|c|c||}
\hline & F & M & ALL \\
\hline To gain working conditions/rights/benefits & 8 & 27 & 35 \\
\hline For protection/security & - & 5 & 5 \\
\hline $\begin{array}{l}\text { To strengthen their position for their own } \\
\text { good/to their advantage }\end{array}$ & 3 & 2 & 5 \\
\hline To support the union & 6 & 6 & 12 \\
\hline Do not like free riders & 1 & 2 & 3 \\
\hline Other & 3 & 3 & 6 \\
\hline & $\mathbf{2 1}$ & $\mathbf{4 5}$ & $\mathbf{6 6 *}$ \\
\hline
\end{tabular}

* This question was asked only of a sub-sample so percentages are meaningless in terms of the whole sample.

In summary, the results have demonstrated that the membership status of most of these employees cannot be adequately explained by compulsion, pressure or ideology. Consequently, the aggregate union membership figures seem to reflect aggregate wishes. This suggests that, with regard to union membership decisions, workplace democracy was already in evidence by May 1991 .

\section{Effects of the legislation on union membership}

Finally, we need to investigate whether membership status continued to reflect wishes in May 1992 in order to demonstrate that the Employment Contracts Act had no dramatic effect on a process already underway. To elicit this information, respondents were asked what method they would choose to negotiate wages and work conditions (see Table 5).

For both samples, the largest group, in each case about half of the sample, wished to be represented by a trade union only. Significantly more males in the recontacts than in the random sample wanted to negotiate an individual contract. The likelihood is that this was a result of the larger manual worker response among the random sample. By disaggregating the data for the recontacts, we were once again able to establish that few had changed their decisions since the year before. The legislation seems not to have caused respondents in our samples to move either towards or against unions, suggesting that decisions had been made prior to the Act, which therefore had little "shock effect". 
Table 5: If you had completely free choice, when negotiating wages and work conditions would you prefer an individual contract, to be represented by a trade union, other (specify)?

\begin{tabular}{||l|c|c|c|c|c|c||}
\hline \hline & \multicolumn{3}{|c||}{ Mecontacts 1992} & \multicolumn{3}{c||}{ Random } \\
\hline & F & M & ALL & F & M & ALL \\
\hline Individual & $13(26)$ & $37(46)$ & $50(38)$ & $18(35)$ & $17(22)$ & $35(27)$ \\
\hline $\begin{array}{l}\text { Represented by } \\
\text { TU }\end{array}$ & $28(56)$ & $34(42)$ & $62(47)$ & $28(55)$ & $44(57)$ & $72(56)$ \\
\hline Other & $05(18)$ & $06(07)$ & $11(08)$ & $03(06)$ & $12(16)$ & $15(12)^{9}$ \\
\hline Don't know & $04(08)$ & $04(05)$ & $08(06)$ & $02(04)$ & $04(05)$ & $06(05)$ \\
\hline & $\mathbf{5 0}$ & $\mathbf{8 1}$ & $\mathbf{1 3 1}$ & $\mathbf{5 1}$ & $\mathbf{7 7}$ & $\mathbf{1 2 8}$ \\
\hline \hline
\end{tabular}

In conclusion, these are interesting findings as they refute the Government's suggestion that workplace democracy was constrained with regard to union membership. This conclusion can be further substantiated: in the May 1991 investigation, employees were asked for their views on compulsory unionism and the results are reported in Appendix 2. A large majority ( 79 percent) and two thirds of members by choice felt that it should be voluntary $^{10}$, although, unsurprisingly, more members than non-members held this opinion $(\mathrm{p}<0.01)$. Overall, in May 1991, the union membership situation reflected workplace democracy, rather than inhibited it. By May 1992, it continued to do so. The hypothesis seems to be upheld.

\section{Discussion and implications}

These are interesting results, first, because they imply that the response at the workplace to the recession had resulted in the existence of a largely democratic membership prior to the legislation. Second, they demonstrate that the level of membership persisted, at least in the short term after the legislation: it might have been expected that some employers would have taken advantage of a piece of legislation which withdrew state support from

Most of these respondents wanted an individual contract but also to be represented by a trade union.

10 Those who thought that membership should be compulsory may have been trying to avert the "free rider" theft because the results also demonstrated that over a third of the respondents showed a clear understanding that it was possible to get union services without being a member. Certainly, with regard to the term "free rider", only a minority claimed not to know its meaning (though there were 37 missing responses): half were able to give a precise definition with respect to unions, a quarter gave an answer that was correct generally and only 10 percent gave an incorrect answer. 
trade unions in order to negotiate a programme of individual contracts. In fact, for these samples, this was not the case at all: in May 1992 employees were questioned whether they had perceived pressures regarding their employment contract. There were only 35 (26 percent) responses from the first sample and, of these, 12 replied in the negative. From the second sample, there were 38 (29 percent) responses, seven of whom replied in the negative. Respondents were asked to provide details (see Table 6). Overall, only four in each sample blamed the union, most of the rest citing the manager/employer. In other words, only an extremely small minority perceived there were any pressures because there were very few respondents to the questions, the positive replies were in the minority and few details were provided. The implication is that, in general, employers did not wish to prevent those who wanted to join a union from doing so. Nor did they object to bargaining with unions: when union members were asked in May 1992 about their current form of bargaining contract (see Table 7), of those who replied (75 percent of recontacts, 74 percent of the random sample) the large majority in collective situations said the union was acting as their bargaining or negotiating agent.

However, these findings must be interpreted with care as other studies have shown that the Act has facilitated some change in form of the bargaining unit (for example, Harbridge and Moulder, 1992) ${ }^{11}$. Our surveys were not concerned with enterprises but with individuals, some of whom had changed or lost their jobs since May 1991, but when we asked members in 1992 about their current bargaining unit, most who responded said they were represented within enterprises.

Nevertheless, it seems that, despite the provisions of the new legislation, for these samples, at this early stage employers were not in general substituting individual for collective negotiations. Instead, they were continuing to bargain with trade unions, albeit in enterprise form. Interestingly, these findings lend support to those reported by Kessler and Bayliss (1992) in a recent British survey of the industrial relations system in Britain which demonstrated that employers had not fully utilised the anti-union legislation of successive Conservative Governments during the 1980 s to weaken union membership.

Why should some New Zealand employers behave like this when, in a time of high unemployment, the new legislation provided them with the wherewithal to severely weaken union membership? The point is that legislation takes effect within a specific historical, cultural and economic context. In the short term at least, the strong tradition of trade union involvement in employment contracts was not overthrown. Employees who wished to be

11 It may be, however, that an unofficial move in this direction had also preceded the legislation: prior. to the passage of the Employment Contracts Act, McAndrew and Hursthouse (1991) carried out a South Island investigation of employer attitudes. Their findings suggested that, on the eve of the legislation, most of the employers they surveyed, far from being hostile to the official industrial relations system, were not very interested in it; indeed, that many employers had been ignoring it. Moreover, a National Business Review nationwide survey in August 1992 (NBR, September 4, 1992: 4) found that three-quarters of the 750 people they contacted said the legislation had made no difference to them personally. 
Table 6: Pressured with regard to employment contract type

\begin{tabular}{|c|c|c|c|c|c|c|}
\hline \multicolumn{7}{|c|}{ May 1992} \\
\hline & \multicolumn{3}{|c|}{ Recontacts } & \multicolumn{3}{|c|}{ Random } \\
\hline & $\mathbf{F}$ & $\mathbf{M}$ & ALL & F & $\mathbf{M}$ & ALL \\
\hline \multicolumn{7}{|l|}{ By whom? } \\
\hline $\begin{array}{l}\text { Colleagues, } \\
\text { union }\end{array}$ & 01 & 01 & 02 & - & 02 & 02 \\
\hline $\begin{array}{l}\text { Management/ } \\
\text { employer }\end{array}$ & 05 & 05 & 10 & 11 & 11 & 22 \\
\hline \multirow{2}{*}{$\begin{array}{l}\text { Government } \\
\text { policy }\end{array}$} & - & 01 & 01 & - & - & - \\
\hline & 06 & 07 & 13 & 11 & 13 & 24 \\
\hline
\end{tabular}

Table 7: If you are in a trade union, is the union acting as your bargaining or negotiating agent?

\begin{tabular}{|c|c|c|c|c|c|c|}
\hline \multicolumn{7}{|c|}{ May 1992} \\
\hline & \multicolumn{3}{|c|}{ Recontacts } & \multicolumn{3}{|c|}{ Random } \\
\hline & $\mathbf{F}$ & $\mathbf{M}$ & ALL & $\mathbf{F}$ & $\mathbf{M}$ & ALL \\
\hline Yes & $17(85)$ & $22(69)$ & $39(75)$ & $21(91)$ & $37(100)$ & $58(97)$ \\
\hline No & $01(05)$ & $08(25)$ & $09(17)$ & $01(04)$ & - & $01(02)$ \\
\hline \multirow[t]{2}{*}{ Don't know } & $02(10)$ & $02(06)$ & $04(08)$ & $01(04)$ & - & $01(02)$ \\
\hline & 20 & 32 & 52 & 23 & 37 & 60 \\
\hline
\end{tabular}

union members continued to be so and were not pressured, for the most part, to do otherwise; in general they wanted the union to act as their bargaining agent and employers recognised that situation. This is unsurprising: there is well-established theory (Freeman and Medoff, 1979) which suggests that unions can have some positive productivity effects. Employers may well have recognised this intuitively through experience of a long tradition 
of collective bargaining: in Britain, Kessler and Bayliss (1992) found that in many cases, employers had worked with unions to carry out productivity and cost-cutting deals ${ }^{12}$.

\section{Conclusions}

It must be noted that our samples over-proportionately represented white collar workers, and that a study of manual workers might produce a different picture. Moreover, these findings may be representative only of Dunedin. Nevertheless, they are interesting in themselves as the departure from the century-old tradition of the practice of industrial relations in New Zealand might have been expected to have been followed by dramatic changes in membership in most workplaces. However, the results demonstrate that, for these samples, in the first year after it was passed the Act had little impact on union membership: that is, most membership decisions reflected rather than inhibited democracy before the legislation was passed and were largely unaffected by it afterwards. Arguments for workplace democracy have underpinned the rationale regarding the Employment Contracts legislation, indeed, have provided the justification for it, so this is an important finding. The implication is that any changes that may have come about as a result of the legislation have not eventuated via the mechanism of the restoration of democracy at the workplace. Furthermore, the Act's provisions were not utilised by most employers to diminish membership levels via an immediate encouragement of individual contracts. Thus, in a century-old tradition of union recognition, the advantages of the existence of trade unions whose membership is based on democratic decision seems to have been recognised, in the short term at least, by most employers.

12 Indeed, the practice of check-off arrangements increased in Britain during the 1980 s, probably to utilise union organisation of the workplace. 


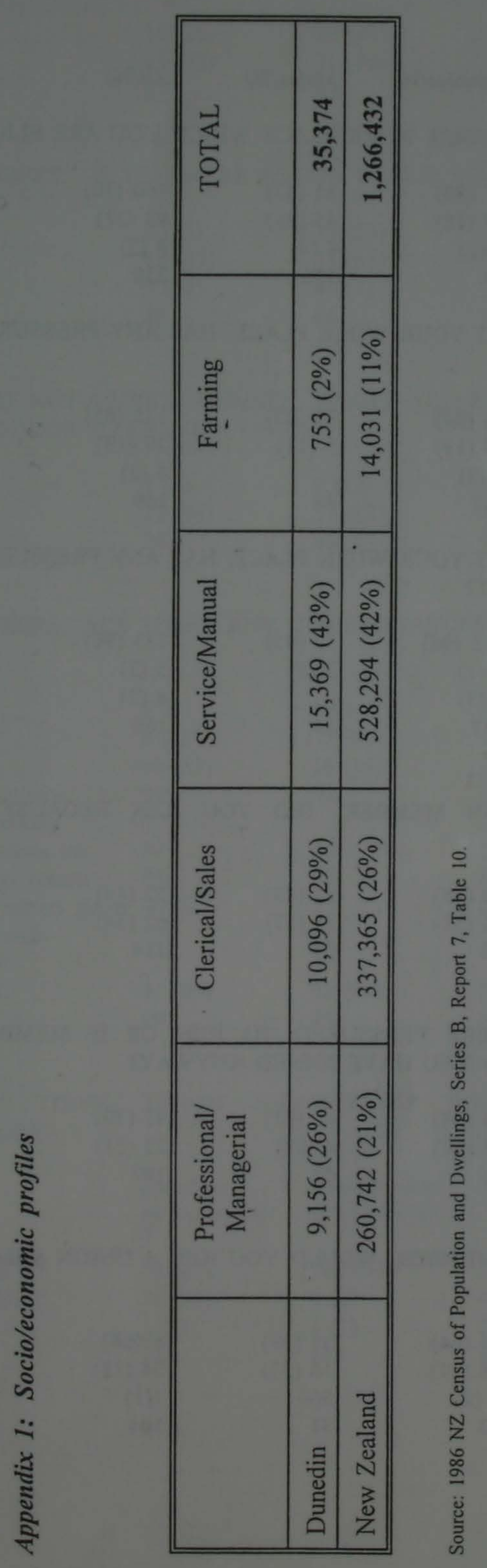


Appendix 2: May 1991 survey (extracts)

Females(\%) Males(\%) All(\%)

Q.1. IS THERE A UNION AT YOUR WORK PLACE WHICH YOU ARE ELIGIBLE TO JOIN?

$\begin{array}{llll}\text { YES } & 75(80) & 85(63) & 160(70) \\ \text { NO } & 17(18) & 45(33) & 62(27) \\ \text { D.K. } & 2(2) & 6(4) & 8(3) \\ & \mathbf{9 4} & \mathbf{1 3 6} & \mathbf{2 3 0}\end{array}$

Q.2. IF THERE IS A UNION AT YOUR WORK PLACE, HAS ANY PRESSURE EVER BEEN PUT ON YOU TO JOIN IT?

$\begin{array}{llll}\text { YES } & 98(84) & 33(87) & 135(85) \\ \text { NO } & 15(13) & 5(13) & 20(13) \\ \text { D.K. } & 4(3) & - & 4(2) \\ & \mathbf{1 1 7} & \mathbf{3 8} & \mathbf{1 5 9}\end{array}$

Q.3. IF THERE IS A UNION AT YOUR WORK PLACE, HAS ANY PRESSURE EVER BEEN PUT ON YOU NOT TO JOIN IT?

$\begin{array}{llll}\text { YES } & 112(96) & 37(95) & 153(96) \\ \text { NO } & 1(1) & 2(5) & 3(2) \\ \text { D.K. } & 4(3) & - & 4(2) \\ & 117 & 39 & 160\end{array}$

Q.4. IF YOU ARE A UNION MEMBER, DID YOU JOIN BECAUSE IT WAS A JOB REQUIREMENT?

$\begin{array}{llll}\text { YES } & 29(48) & 23(43) & 52(46) \\ \text { NO } & 31(52) & 31(57) & 62(54) \\ & \mathbf{6 0} & \mathbf{5 4} & \mathbf{1 1 4}\end{array}$

Q.5. MEMBERS: IF YOU WERE PRESSURED TO JOIN OR IF MEMBERSHIP IS A JOB REQUIREMENT, WOULD YOU HAVE JOINED ANYWAY?

$\begin{array}{llll}\text { YES } & 38(68) & 47(92) & 85(79) \\ \text { NO } & 18(32) & 4(08) & 22(21) \\ & \mathbf{5 6} & \mathbf{5 1} & \mathbf{1 0 7}\end{array}$

Q.6. IF YOU ARE A UNION MEMBER, WOULD YOU JOIN A UNION WHATEVER YOUR JOB OR FIRM?

$\begin{array}{llll}\text { YES } & 34(64) & 35(69) & 69(66) \\ \text { NO } & 18(34) & 16(31) & 34(33) \\ \text { D.K. } & 1(2) & 0(-) & 1(1) \\ & \mathbf{5 3} & \mathbf{5 1} & \mathbf{1 0 4}\end{array}$


Q.7. IF YOU ARE A UNION MEMBER, WOULD YOU EVER TRY TO PERSUADE NON-MEMBERS TO JOIN?

$\begin{array}{llll}\text { YES } & 16(28) & 22(42) & 38(35) \\ \text { NO } & 41(72) & 31(58) & 72(65) \\ & \mathbf{5 7} & \mathbf{5 3} & \mathbf{1 1 0}\end{array}$

Q.8. NON-MEMBERS: IF YOU WERE ASKED, WOULD YOU JOIN A UNION?

\begin{tabular}{llll|} 
YES & $7(25)$ & $15(23)$ & $22(23)$ \\
NO & $16(57)$ & $43(65)$ & $59(63)$ \\
D.K. & $5(18)$ & $8(12)$ & $13(14)$ \\
& 28 & 66 & 94
\end{tabular}

Q.9. IF YOU ARE NOT A UNION MEMBER, WOULD YOU EVER TRY TO PERSUADE ANYONE NOT TO JOIN OR TO LEAVE A UNION?

$\begin{array}{llll}\text { YES } & 1(4) & 8(12) & 9(10) \\ \text { NO } & 27(96) & 57(88) & 84(90) \\ & 28 & 65 & 93\end{array}$

Q.10. NON-MEMBERS; ARE THERE ANY CIRCUMSTANCES IN WHICH YOU WOULD JOIN A UNION?

\begin{tabular}{|c|c|c|c|}
\hline \multirow{3}{*}{$\begin{array}{l}\text { NO } \\
\text { YES }\end{array}$} & $\mathbf{F} \%$ & $\mathbf{M} \%$ & ALL\% \\
\hline & $8(42)$ & $27(60)$ & $35(55)$ \\
\hline & $10(53)$ & $16(36)$ & $26(41)$ \\
\hline $\begin{array}{l}\text { definitely } \\
\text { if union. }\end{array}$ & 01 & 02 & 03 \\
\hline interests me & 04 & 05 & 09 \\
\hline other reason & 03 & 03 & 06 \\
\hline no reason given & 00 & 05 & 05 \\
\hline depends & 02 & 01 & 03 \\
\hline OT SURE/ & & & \\
\hline OUBTFUL & $\begin{array}{l}01(05) \\
19\end{array}$ & $\begin{array}{l}02(04) \\
45\end{array}$ & $\begin{array}{l}03(05) \\
64\end{array}$ \\
\hline
\end{tabular}

Q.11. DO YOU THINK UNION MEMBERSHIP SHOULD BE VOLUNTARY OR COMPULSORY?

$\begin{array}{llll} & \begin{array}{l}\text { Members } \\ \text { by choice(\%) }\end{array} & \begin{array}{l}\text { Non-Members } \\ \text { by choice(\%) }\end{array} & \text { All (\%) } \\ \text { VOLUNTARY } & 76(67) & 106(95) & 182(81) \\ \text { COMPULSORY } & 36(32) & 4(4) & 40(18) \\ \text { D.K. } & 1(1) & 1(1) & 2(1) \\ & 113 & 111 & \mathbf{2 2 4}\end{array}$


Appendix 3: A summary of membership patterns (May 1991)

1. Those who are currently members

$114(50)$

Those who are currently non-members

$108(47)$

Don't know

6 (3)

2.(a) Those who currently want to be members

- Existing members (i.e.) have joined by free choice)

- Existing non-members (i.e. want to join)

(b) Those who currently want to be non-members

- Existing members (i.e. only joined because pressured/job requirement)

- Existing non-members (i.e. not join in any circumstances)

(c) Those who don't know

- Members

- Non-members

3.(a) Members: would you be a member in any situation?

- Yes

- No

34 (33)

- Don't know

1 (1)

$104(62)$

(b) Non-members: would you be a non-member in any situation?

- Yes

- No

- Don't know 


\section{References}

Cregan, C. and Johnston, S. (1990), An Industrial Relations Approach to the Free Rider Problem: Young People and Trade Union Membership, British Journal of Industrial Relations, 28(1): 84-104.

Cregan, C. and Johnston, S. (1991), Young People and Trade Union Membership: An International Comparative Study, The Economic and Labour Relations Review, 3(2): 165179.

Crocombe, G.T., Enright, M.J. and Porter, M.E. (1991), Upgrading New Zealand's Competitive Advantage, Oxford University Press, Auckland.

Department of Labour (1992), Wellington, Contract: the Report on Current Industrial Relations in New Zealand, pp.1-4.

Department of Labour (1991), Wellington, Key Statistics, December.

Freeman, R. and Medoff, J. (1979), The Two Faces of Unionism, The Public Interest, No. 57.

Harbridge, R. (1991), Collective Bargaining Coverage in New Zealand: the Early Effects of New Legislative Arrangements, Working Paper 6/91, Industrial Relations Centre, Victoria University of Wellington, June.

Harbridge, R. and Moulder, J., (1992), Collective Bargaining and New Zealand's Employment Contracts Act 1991: One Year On, Working Paper 4/92, Industrial Relations Centre, Victoria University of Wellington, April.

Hirschman, A.O., (1970), Exit, Voice and Loyalty: Responses to Declines in Firms, Organisations and States, Harvard University Press, Cambridge, Mass.

Kessler, S. and Bayliss, F., (1992), Contemporary British Industrial Relations, Macmillan, Basingstoke.

McAndrew, I. (1992), The Structure of Bargaining under the Employment Contracts Act, New Zealand Journal of Industrial Relations, 17(3): 259-282.

McAndrew, I. and Hursthouse, P. (1991), Reforming Labour Relations: What Southern Employers Say, New Zealand Journal of Industrial Relations, 16(1): 1-11.

National Party Manifesto (1991), Wellington, Creating a Decent Society: a Programme for Positive Action, National Party Policies for the 1990s.

Olson, M. (1965), The Logic of Collective Action: Public Goods and the Theory of Groups, Harvard University Press, Cambridge, Mass. 